\title{
Performance of common bean genotypes as a function of growing seasons and technological input levels ${ }^{1}$
}

\author{
Rodrigo Zanella ${ }^{2}$, Daniela Meira², Andrei Daniel Zdziarski², \\ Antonio Pedro Brusamarello², Paulo Henrique de Oliveira ${ }^{2}$, Giovani Benin ${ }^{2}$
}

\begin{abstract}
In Brazil, common bean (Phaseolus vulgaris L.) is cultivated in different growing seasons and environments, with different genotypes responses due to the genotype $\mathrm{x}$ environment interaction. This study aimed to identify common bean genotypes with a better production stability in each growing environment. The trials were conducted in a randomized block design, with three replications, involving three growing years, nine common bean genotypes and four environments (first and second growing seasons with high and low levels of technological input, such as fertilizers and pest and disease control). Biplot analyses were performed using the GGE Biplot software. The use of high levels of technological input results in an average increase of $14.4 \%$ for yield and is more representative in the crop environments, as well as more adequate for genotype selection. IPR Campos Gerais, BRS Esplendor and BRS Campeiro showed a high stability and presented the best productive performance under both technological levels.
\end{abstract}

KEYWORDS: Phaseolus vulgaris L., genotype $\mathrm{x}$ environment interaction, grain yield.

\section{INTRODUCTION}

Common bean (Phaseolus vulgaris L.) is an excellent source of proteins, carbohydrates and minerals. Brazil is one of the world's largest producers and consumers. In the 2018/2019 crop season, 2.9 million ha were cultivated, with a production of 3.07 million $t$ (Conab 2019).

Beans are cultivated under different seasons and conditions (Lima et al. 2013). The growing season is divided into first (rainy season, with sowing carried out between August and December), second (dry season, from January to April) and third (winter season, from May to July) season (Moura \& Brito

\section{RESUMO}

Desempenho de genótipos de feijão comum em função de estações de cultivo e níveis tecnológicos de insumos

No Brasil, o feijoeiro (Phaseolus vulgaris L.) é cultivado em diferentes safras e ambientes, com diferentes respostas do genótipo devido à interação genótipo $\mathrm{x}$ ambiente. Objetivou-se identificar genótipos de feijão com melhor estabilidade produtiva em cada ambiente de cultivo. Os experimentos foram conduzidos em delineamento de blocos casualizados, com três repetições, envolvendo três anos agrícolas, nove genótipos de feijão comum e quatro ambientes (primeira e segunda safras com baixo e alto nível tecnológico de insumos, como fertilizantes, controle de pragas e doenças). Análises biplot foram realizadas utilizandose o software GGE Biplot. O uso de alto nível tecnológico de insumos resulta em aumento de $14,4 \%$ na produtividade, é mais representativo nos ambientes de cultivo e mais adequado para a seleção de genótipos. IPR Campos Gerais, BRS Esplendor e BRS Campeiro mostraram alta estabilidade e obtiveram o melhor desempenho produtivo em ambos os níveis tecnológicos.

PALAVRAS-CHAVE: Phaseolus vulgaris L., interação genótipo $\mathrm{x}$ ambiente, produtividade de grãos.

2015). The first growing season presents a greater productive potential, because of the greater water availability, closer to ideal temperatures for the crop and higher radiation than in the dry season. The winter harvest is not carried out in the south of the Paraná state due to the formation of frost in this period.

The range of environments and multiple growing seasons result in a complex genotype $x$ environment interaction (Pereira et al. 2009, Torga et al. 2013), which affects the grain yield (Melo et al. 2007, Gonçalves et al. 2010). Furthermore, that interaction is dependent of local and meteorological conditions (temperature, relative humidity, solar

1. Received: Sep. 25, 2018. Accepted: May 21, 2019. Published: Jul. 11, 2019. DOI: 10.1590/1983-40632019v4954989.

2. Universidade Tecnológica Federal do Paraná, Departamento de Agronomia, Pato Branco, PR, Brasil.

E-mail/ORCID: zanella_rodrigo@hotmail.com/0000-0002-7278-8613,dmdanielameira94@gmail.com/0000-0001-7843-4472,

dz_andrei@hotmail.com/0000-0002-6051-1836, antoniopedro1991@hotmail.com/0000-0002-2947-0052, phenriqueoliveira@gmail.com/0000-0001-5452-9354, benin@utfpr.edu.br/0000-0002-7354-5568. 
radiation and precipitation), while the genotype performance depends on environmental variations (Ramalho et al. 1998, Matos et al. 2007). These local variations affect the plant development - they may change the plant growth cycle (Luo 2011) - and also cause a greater or lesser incidence of diseases (Alves \& Pozza 2010, Juroszek \& Von Tiedemann 2011)

Several factors contribute to the production instability and low average grain yield in Brazil, which was $1,030 \mathrm{~kg} \mathrm{ha}^{-1}$ in the 2018/2019 crop season (Conab 2019). Inadequate agronomic parameters and soil management, since the crop is affected by several root diseases (mainly Fusarium oxysporum, Fusarium solani and Rizoctonia) (Montanari et al. 2010); environmental variations, where the water deficit and high temperatures mainly in reproductive periods cause a decrease in yield, ranging from $43 \%$ to $73 \%$, depending on the genotype (Beebe et al. 2013, Dipp et al. 2017); and low seed quality, with low vigor, germination and source of disease inoculum, provide a production instability (Carvalho et al. 2011). Thus, it is essential to evaluate and identify adapted and stable genotypes in different environments and types of management. Understanding the genotype $\times$ environment interaction is critical for deploying superior genotypes to each environment (Bruno et al. 2017).

Several practices can be adopted to minimize the biotic and abiotic factors that reduce the grain yield in beans. This crop responds to fertilization input (Santos et al. 2015), weed control (Barroso et al. 2010, Machado et al. 2015) and insect and diseases control (Cunha et al. 2005, McCreary et al. 2016). The identification of adaptable and stable genotypes is the best alternative to decreasing the genotype $\times$ environment interaction with the aim of increasing the grain yield and production stability (Silva et al. 2013, Azevedo et al. 2015, Barili et al. 2015). Azevedo et al. (2015) and Santos et al. (2019) point out the importance of multi-environmental trials to verify the stability and adaptability of common bean crop cultivars, both for the recommendation of cultivars and the selection of lineages for release.

The multivariate statistics facilitates the understanding of complex genotype $\times$ environment interactions. Among the multivariate methodologies, the GGL + GGE analysis [(genotype main effects + genotype $\times$ location interaction $)+($ genotype main effects + genotype $\times$ environment interaction)] was proposed by Yan $(2014,2015)$. This methodology is superior because it allows inferences in the genotype performance, environment and the interaction among them, enabling more accurate results and improving the interpretation via biplot (Yan 2014, 2015, 2016). These analyses have been successfully used in several crops, such as soybean (Matei et al. 2017), wheat (Bornhofen et al. 2017), rice (Chi et al. 2018, Sairekha et al. 2018), cowpea (Souza et al. 2018) and common bean (Azevedo et al. 2015, Hoyos-Villegas et al. 2016, Sozen et al. 2018, Santos et al. 2019).

Thus, this study aimed to identify common bean genotypes with a better production stability in each growing environment.

\section{MATERIAL AND METHODS}

The field trials were conducted in Pato Branco, Paraná state, Brazil (26 $10^{\circ} 32^{\prime \prime} \mathrm{S}, 52^{\circ} 41^{\prime} 27^{\prime \prime} \mathrm{W}$ and average altitude of $760 \mathrm{~m}$ ), under a Cfa climate, according to the Köppen classification (Alvares et al. 2013), and with soil classified as a typical Dystrophic Red Latosol (Santos et al. 2013) or Typic Hapludox (USDA 2014). The experimental area has been cultivated under a no-tillage system for 15 years. The soil presents $750 \mathrm{~g} \mathrm{~kg}^{-1}$ of clay, $1.4 \mathrm{~g} \mathrm{~kg}^{-1}$ of sand and $248.6 \mathrm{~g} \mathrm{~kg}^{-1}$ of silt. The chemical characteristics of the soil were as it follows: $\mathrm{pH}\left(\mathrm{CaCl}_{2}\right): 4.8$; organic matter (wet combustion): $50.93 \mathrm{~g} \mathrm{dm}^{-3} ; \mathrm{P}$ (Mehlich-1): $6.68 \mathrm{mg} \mathrm{dm}^{-3}$; K (Mehlich-1): $0.43 \mathrm{cmolc} \mathrm{dm}^{-3}$; cation exchange capacity: $12.6 \mathrm{cmolc} \mathrm{dm}^{-3}$; and V: $56.59 \%$. The values of $\mathrm{P}$ and $\mathrm{K}$ are classified as high and very high, respectively (SBCS 2004).

The used experimental design was a randomized complete block, with three replications. The plots consisted of four lines ( $4 \mathrm{~m}$-long spaced at $0.45 \mathrm{~m}$, totaling an area of $7.2 \mathrm{~m}^{2}$ ) and density was 240,000 plants ha-1 ${ }^{-1}$ The treatments formed a $3 \times 9 \times 4$ factorial scheme [3 years corresponding to the 2013/2014, 2014/2015 and 2015/2016 crop seasons; 9 common bean genotypes (Table 1); and 4 environments, being first and second growing seasons with both high and low technology (Table 2)]. Sowing in the first and second growing seasons was carried out in the first half of November and February, respectively. The meteorological conditions during the common bean development were ideal to the crop. The daily average temperature ranged from $20.8^{\circ} \mathrm{C}$ to $21.3^{\circ} \mathrm{C}$, considering both growing years. 
The base fertilization comprised $300 \mathrm{~kg} \mathrm{ha}^{-1}$ of mineral fertilizer in the formulation N-P-K 08-20-15, with an expected yield of $3.5 \mathrm{t} \mathrm{ha}^{-1}$ (SBCS 2004). In addition, an over fertilization was applied at 15-20 days after the emergence, in the phenological stage $\mathrm{V}_{3}-\mathrm{V}_{4}$, with the dose of $100 \mathrm{~kg} \mathrm{ha}^{-1}$ of urea $46-0-0$. The production input used at each level of yield input, high or low technology (Table 2), represents the wide input range used in Brazil and is equivalent to different grain yield expectations.
The useful area of the plots was harvested manually, followed by mechanized threshing. Two lateral lines and $0.5 \mathrm{~m}$ of both ends of the plot were disregarded, resulting in a useful area of $2.7 \mathrm{~m}^{2}$. The harvested common bean grains were weighed and transformed to $\mathrm{kg} \mathrm{ha}^{-1}$, being expressed on a $13 \%$ water basis content.

The data were analyzed by the GGE Biplot software (Yan 2001), while the analysis of ideal genotype was performed for each technology level and growing season, to identify the best genotype

Table 1. Description of common bean genotypes and growing environments.

\begin{tabular}{|c|c|c|c|c|}
\hline Genotype & Code & Cycle (days) & Growth habit & Group \\
\hline BRS Campeiro & G1 & $75-85$ & Indeterminate Type II & Black-seeded \\
\hline BRS Esplendor & G2 & $85-90$ & Indeterminate Type II & Black-seeded \\
\hline IPR Tuiuiú & G3 & 88 & Indeterminate Type II & Black-seeded \\
\hline BRS Ametista & G4 & $85-94$ & Indeterminate Type II & Carioca-seeded \\
\hline BRS Estilo & G5 & $85-90$ & Indeterminate Type II & Carioca-seeded \\
\hline IAPAR 81 & G6 & 92 & Indeterminate Type II & Carioca-seeded \\
\hline IPR Campos Gerais & G7 & 88 & Indeterminate Type II & Carioca-seeded \\
\hline IPR Curió & G8 & 70 & Determinate Type I & Carioca-seeded \\
\hline IPR Tangará & G9 & 87 & Indeterminate Type II & Carioca-seeded \\
\hline Growing environment & \multicolumn{2}{|c|}{ Growing season } & \multicolumn{2}{|c|}{ Technology level } \\
\hline 1 & \multicolumn{2}{|c|}{ First growing season } & \multicolumn{2}{|c|}{ High } \\
\hline 2 & \multicolumn{2}{|c|}{ First growing season } & \multicolumn{2}{|c|}{ Low } \\
\hline 3 & \multicolumn{2}{|c|}{ Second growing season } & \multicolumn{2}{|c|}{ High } \\
\hline 4 & \multicolumn{2}{|c|}{ Second growing season } & \multicolumn{2}{|c|}{ Low } \\
\hline
\end{tabular}

Table 2. Description of technological input levels during the common bean development cycle.

\begin{tabular}{|c|c|c|c|c|c|c|}
\hline \multicolumn{7}{|c|}{ Fertilizes } \\
\hline \multirow{2}{*}{ Input } & \multirow{2}{*}{ Formulation } & \multirow{2}{*}{\multicolumn{2}{|c|}{ Dose $\left(\mathrm{kg} \mathrm{ha}^{-1}\right)$}} & \multirow{2}{*}{$\begin{array}{l}\text { Application } \\
\text { (DAS) }\end{array}$} & \multicolumn{2}{|c|}{ Technology } \\
\hline & & & & & High & Low \\
\hline Base fertilization & \multicolumn{3}{|l|}{ NPK 08-20-15 } & 0 & $\mathrm{x}$ & \multirow[t]{2}{*}{$\mathrm{x}$} \\
\hline Nitrogen fertilization & Urea $46-00-00$ & 100 & & $15-20$ & $\mathrm{x}$ & \\
\hline \multicolumn{7}{|c|}{ Chemical input } \\
\hline \multirow{2}{*}{ Input } & \multirow{2}{*}{\multicolumn{2}{|c|}{ Active ingredient }} & \multirow{2}{*}{ Dose (g.a.i ha-1) } & \multirow{2}{*}{$\begin{array}{l}\text { Application } \\
(\mathrm{DAS}) * * *\end{array}$} & \multicolumn{2}{|c|}{ Technology } \\
\hline & & & & & High & Low \\
\hline Seed treatment & Carbendazin + thirar & an and fipronil & $45+105$ and $50^{*}$ & - & $\mathrm{x}$ & \\
\hline Seed inoculation & Rhizobium tropici $\mathrm{st}$ & train 4080 & $100 * *$ & - & $\mathrm{x}$ & $\mathrm{x}$ \\
\hline Weed control & Fomesafem + fluazif & ifope-p-butilico & $200+200$ & $15-20$ & $\mathrm{x}$ & $\mathrm{x}$ \\
\hline Insects control 1 & Imidalocloprido $+\mathrm{b}$ & seta-ciflutrina & $100+12.5$ & $15-20$ & $\mathrm{x}$ & $\mathrm{x}$ \\
\hline Disease control 1 & Trifloxistrobina + te & ebuconazol and carbendazin & $75+150$ and 250 & $30-35$ & $\mathrm{x}$ & \\
\hline Insects control 2 & Tiametoxam + lamb & bda-cialotrina and espiromesifeno & $14.1+10.6$ and 120 & $30-35$ & $\mathrm{x}$ & $\mathrm{x}$ \\
\hline Disease control 2 & Azoxistrobina + dife & enoconazol and tiofanato metílico & $100+72.5$ and 250 & $46-51$ & $\mathrm{x}$ & \\
\hline Insects control 3 & Tiametoxam + lamb & bda-cialotrina and espiromesifeno & $14.1+10.6$ and 120 & $62-67$ & $\mathrm{x}$ & \\
\hline Disease control 3 & Fentin hydroxide & & 400 & $62-67$ & $\mathrm{x}$ & \\
\hline
\end{tabular}

* Dose to $100 \mathrm{~kg}$ of seeds; ** dose (g) for $50 \mathrm{~kg}$ of seeds; *** interval of days after sowing in which the input was performed; g. a. i.: grams of active ingredient; DAS: days after sowing. 
at each technological level and growing season over the years. The analysis of genotypes and environment association allow to identify which genotypes are associated (have a better yield) with each environment. The angle between the vectors represents the genetic correlation (Yan 2014). Angles smaller than $90^{\circ}$ represent a positive association between environments and genotypes, and angles larger than $90^{\circ}$ represent a negative association (Yan 2014).

The GGL + GGE analysis [(genotype main effect + genotype $\times$ location interaction $)+($ genotype main effect + genotype $\times$ environment interaction)] allows to evaluate environments in multi-year trials in a single biplot. Thus, in this biplot, the smaller angle between the environment and the average environment shows a greater representativeness. Likewise, when there is a smaller angle between the environments, the genetic correlation between them will be greater. When the data scaling method is based on the standard deviation (SD) + adjusted heritability $(H)$ (scaling 2), the vector length corresponds to the square root of $H$ (Yan \& Holland 2010). Herewith, this scaling is the most adequate to evaluate trial environments, in terms of its representativeness and discrimination power.

For the genotype $\times$ environment interaction analyses and associations between environments and genotypes, scaling 1 (SD standard data) was used, where all environments have similar vector sizes and thus similar weights in the joint analysis. For the GGL + GGE analysis, scaling 2 was used (data standardized by SD and $H$-adjusted), as this method allows inferences about the representativeness and environmental discrimination power (Yan \& Holland 2010). For the genotype $\times$ environment interaction analysis, the singular value partition (SVP) was $=1$, focusing on the genotype. For the environment analysis, $\mathrm{SVP}=2$, the analysis focused on the environment, because it seeks to identify associations between environments, as well as the discrimination power of the same. Multivariate analyzes were performed using the GGE Biplot software (Yan 2001).

The interaction among growing years $x$ common bean genotypes $\times$ environments was tested using analysis of variance by the $F$-test $(\mathrm{p}<0.05)$, after the assumptions of homogeneity of variances and normality of the residues were attended. The mean values were compared by the Scott-Knott test $(\mathrm{p}<0.05)$, using the Genes software (Cruz 2016).

\section{RESULTS AND DISCUSSION}

The analysis of variance (Table 3 ) revealed a triple interaction for the growing years $(\mathrm{Y}) \mathrm{x}$ common bean genotypes $(\mathrm{G}) \mathrm{x}$ environments $(\mathrm{E})$, indicating the presence of a genotype $\mathrm{x}$ environment interaction, and differentiated performance of genotypes over the growing years and environments. The triple interaction indicates that the genotype behavior is modified against the tested environments. Therefore, the grain yield is mainly affected by the growing environment. These results corroborate some studies with bean crops (Sozen et al. 2008, Santos et al. 2019). In this way, the interactions $G \times E$ were explained by the adaptability and stability analyses.

A genotype is more desirable if it is located closer to the "ideal" genotype (Kaya et al. 2006). The circles in Figure 1 represent what would be the ideal performance of a hypothetical genotype, which has a maximum yield and good stability. In the growing years 2013, 2014 and 2015, under high-technology environments (Figure 1A), regardless of the first or second growing season, IPR Campos Gerais (G7) was the closest to the ideal. BRS Ametista (G4), BRS Campeiro (G1) and BRS Esplendor (G2) can also be highlighted, since they had a superior performance, if compared to the others genotypes, with higher

Table 3. Summary of the analysis of variance for grain yield (GY) of common bean genotypes as a function of the years (2013, 2014 and 2015) and environment input (first growing season under high and low technology and second growing season under high and low technology).

\begin{tabular}{|c|c|c|}
\hline $\begin{array}{l}\text { Source of } \\
\text { variation }\end{array}$ & $\begin{array}{l}\text { Degrees of } \\
\text { freedom }\end{array}$ & $\begin{array}{l}\text { Mean square } \\
(\mathrm{GY})\end{array}$ \\
\hline$(\mathrm{Block} / \mathrm{E}) / \mathrm{Y}$ & 24 & $94,301.2$ \\
\hline Genotype (G) & 8 & $1,855,332.7 * *$ \\
\hline Growing year (Y) & 2 & $30,757,459.3 * *$ \\
\hline Environment (E) & 3 & $6,431,822.7 * *$ \\
\hline Gx Y & 16 & $455,237.7 * *$ \\
\hline$G \times E$ & 24 & $184,433.9^{\text {ns }}$ \\
\hline Y x E & 6 & $2,596,975.5 * *$ \\
\hline$G \times Y \times E$ & 48 & $263,333.6^{* *}$ \\
\hline Residual & 192 & $154,168.5$ \\
\hline Mean & & $2,666.9$ \\
\hline CV $(\%)$ & & 14.7 \\
\hline
\end{tabular}



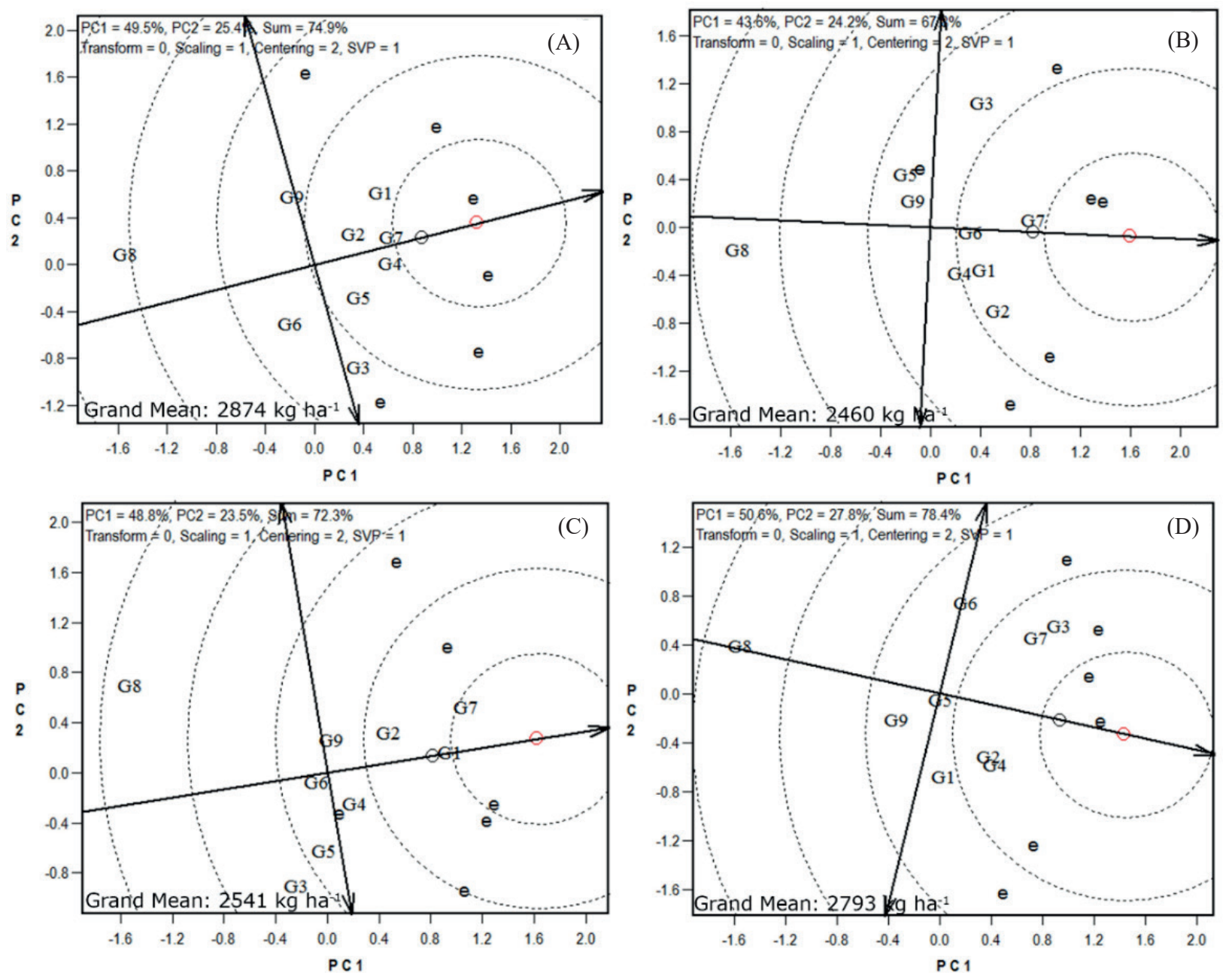

Figure 1. Ideal genotype classification based on its performance under high (A) and low (B) technological input, first (C) and second (D) growing season, according to the GGE biplot analysis, for the grain yield of nine common bean genotypes. G1: BRS Campeiro; G2: BRS Esplendor; G3: IPR Tuiuiú; G4: BRS Ametista; G5: BRS Estilo; G6: IAPAR 81; G7: IPR Campos Gerais; G8: IPR Curió; G9: IPR Tangará.

yield and good stability. For the low technology (Figure 1B), IPR Campos Gerais (G7) presented the best performance, with a good stability and high productivity in the three growing years. BRS Esplendor (G2), BRS Campeiro (G1) and IPR 81 (G6) presented a performance similar to the ideal genotype.

IPR Curió (G8) was the furthest from the ideal genotype, in both the high and low technological inputs. It is the only genotype with determined type-I growth habit, which has a lower phenotypic stability. Therefore, Heinemann et al. (2016), studying bean cultivars under water stress, showed that an earlier cycle may be an advantage, because of the escape from terminal drought. IPR Campos Gerais (G7) has an indeterminate type-II growth habit and a long cycle, with competitive advantages when cultivated under unfavorable environments (drought stress, pest attack, weed competition, less nutrient availability, etc.), because of its high vegetative growth, greater branching capacity and flowering period being important traits to support the plant during stress periods in the crop cycle. Genotypes with undetermined growth habits, such as IPR Campos Gerais (G7) with its indeterminate growth habit (type II), that presents longer flowering periods, are more adapted to variable climate conditions, and have a high tolerance to drought, if compared to genotypes with type-I growth habits (Tohme et al. 1995, Rosales-Serna et al. 2004, Beebe et al. 2011).

Genotypes with determined growth habits are less efficient in their nutrient absorption (Devi et al. 
2013, Trindade \& Araújo 2014) than genotypes with growth habits II and III and, thus, they require the use of high-technology methods, due to their lower genotype stability. A supply of $\mathrm{N}$ to common bean is practicable and essential for higher yields, due to its symbiotic process being inefficient (Fageria et al. 2014, Farid et al. 2016, Argaw \& Muleta 2017).

For the first growing season (Figure 1C), the most suitable genotype was IPR Campos Gerais (G7), followed by BRS Campeiro (G1) and BRS Esplendor (G2). In the second growing season (Figure 1D), BRS Ametista (G4), IPR Tuiuiú (G3), BRS Esplendor (G2) and IPR Campos Gerais (G7) were the closest to the ideal genotype. BRS Esplendor (G2) and IPR Campos Gerais (G7) were adapted in both the growing seasons, due to good adaptability. These results corroborate those of Pereira et al. (2018), where BRS Esplendor had a high grain yield and tolerance to main diseases in a set of 17 genotypes evaluated in the southern region of Brazil. Euzebio et al. (2018) showed the best performance of IPR Campos Gerais in face of unfavorable environments. Genotypes of indeterminate growth habit with a good resistance to diseases, such as BRS Esplendor (G2) and IPR Campos (G7), have a greater performance at distinct environmental conditions, having a longer flowering period and a higher leaf and branch production, indicating a better performance.
Regarding the average performance of the genotypes, regardless of growing years and environment, IPR Campos Gerais (G7) was the closest to the ideal genotype, with a high yield and good stability throughout the growing years 2013, 2014 and 2015 (Figure 2), indicating that it is a genotype of wide adaptation and stability. Barili et al. (2015), studying 40 common bean cultivars with Carioca grain, showed that IPR Campos Gerais (G7) has an above-average performance, wide adaptation and high performance and stability. In addition, BRS Campeiro (G1), BRS Esplendor (G2) and BRS Ametista (G4) presented a good performance in the evaluated environments, and were considered close to the ideal. BRS Esplendor (G2) and BRS Ametista (G4) showed resistance to the main anthracnose breeds (Colletotrichum lindemuthianum) and an intermediate reaction to Fusarium wilt (Fusarium spp.), the main diseases affecting the study region. This genotype is recommended for organic cultivation due to its tolerance to diseases, what explains its good performance (Costa et al. 2009, Melo et al. 2012).

BRS Ametista(G4) showed the best performance in the growing year 2013, in the first growing season, with high technology (environment 1). Under low technology (environment 2), BRS Campeiro (G1) and BRS Esplendor (G2) had the best performance

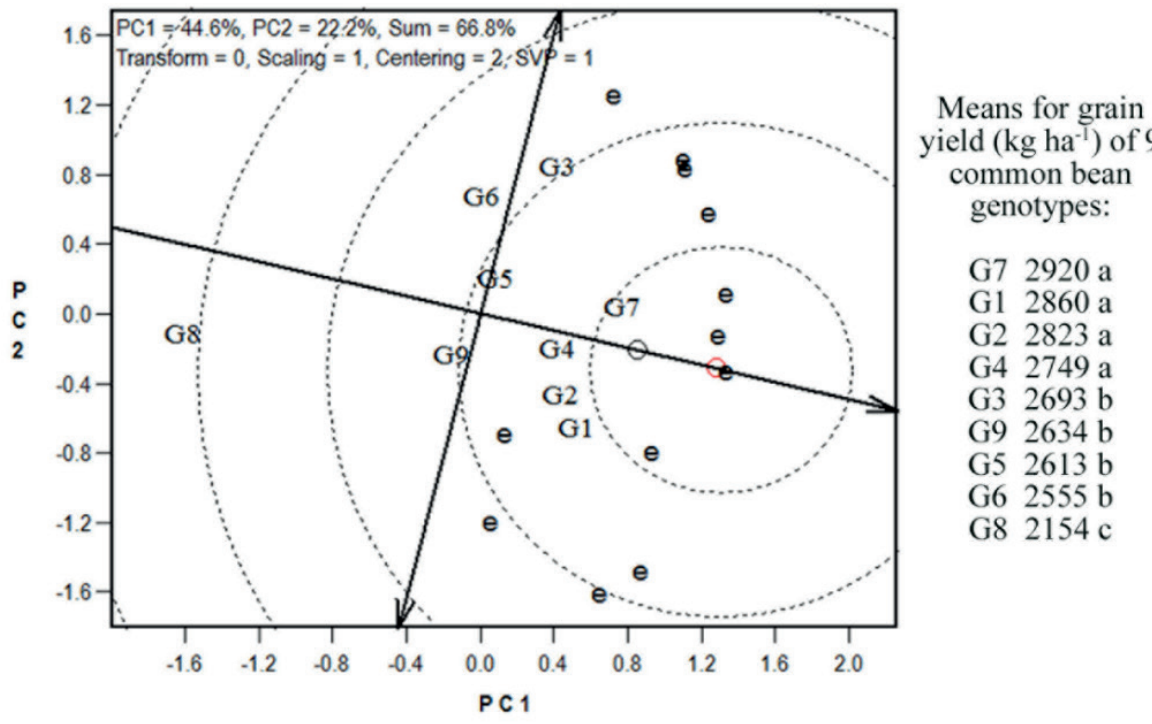

Figure 2. Ideal genotype classification based on the performance at levels of technology or growing season, according to the GGE biplot analysis for grain yield, and means compared by the Scott-Knott test ( $\mathrm{p} \leq 0.05)$. G1: BRS Campeiro; G2: BRS Esplendor; G3: IPR Tuiuiú; G4: BRS Ametista; G5: BRS Estilo; G6: IAPAR 81; G7: IPR Campos Gerais; G8: IPR Curió; G9: IPR Tangará. 
(Figure 3A). For the second growing season with high technology (environment 3), BRS Esplendor (G2) had better performances under low technology (environment 4) and BRS Ametista (G4) was the most stable and productive (Figure 3A). BRS Ametista (G4) and BRS Esplendor (G2) may be highlighted due to their good resistance to diseases (Costa et al. 2009, Melo et al. 2012), indeterminate growth habit and normal cycle, and they have a greater phenotypic performance.

IPR Curió (G8) showed a good performance for the first growing season with high technology (environment 1), in the growing year 2014 (Figure 3B); however, when it was subjected to low technology (environment 2), it did not show a good performance. This may be explained by the low stability of this cultivar and the high environmental effect. This cultivar demands a high cultural input to show its productive potential. In this way, a good initial development, obtained through the use of nitrogen and better control of pests and diseases, allows a greater performance for the genotype.

In this condition, IPR Campos Gerais (G7), BRS Campeiro (G1) and BRS Esplendor (G2) stand out due to their higher adaptability and stability. These genotypes may be cultivated under low technological input. In the second growing season under high technology (environment 3), BRS Estilo (G5) showed the best performance, followed by IPR Tuiuiú (G3), which had the best performance under low technology (environment 4), in 2014.

In the first growing season of 2015 (Figure 3B), under high and low technology (environment 1 and 2 ,
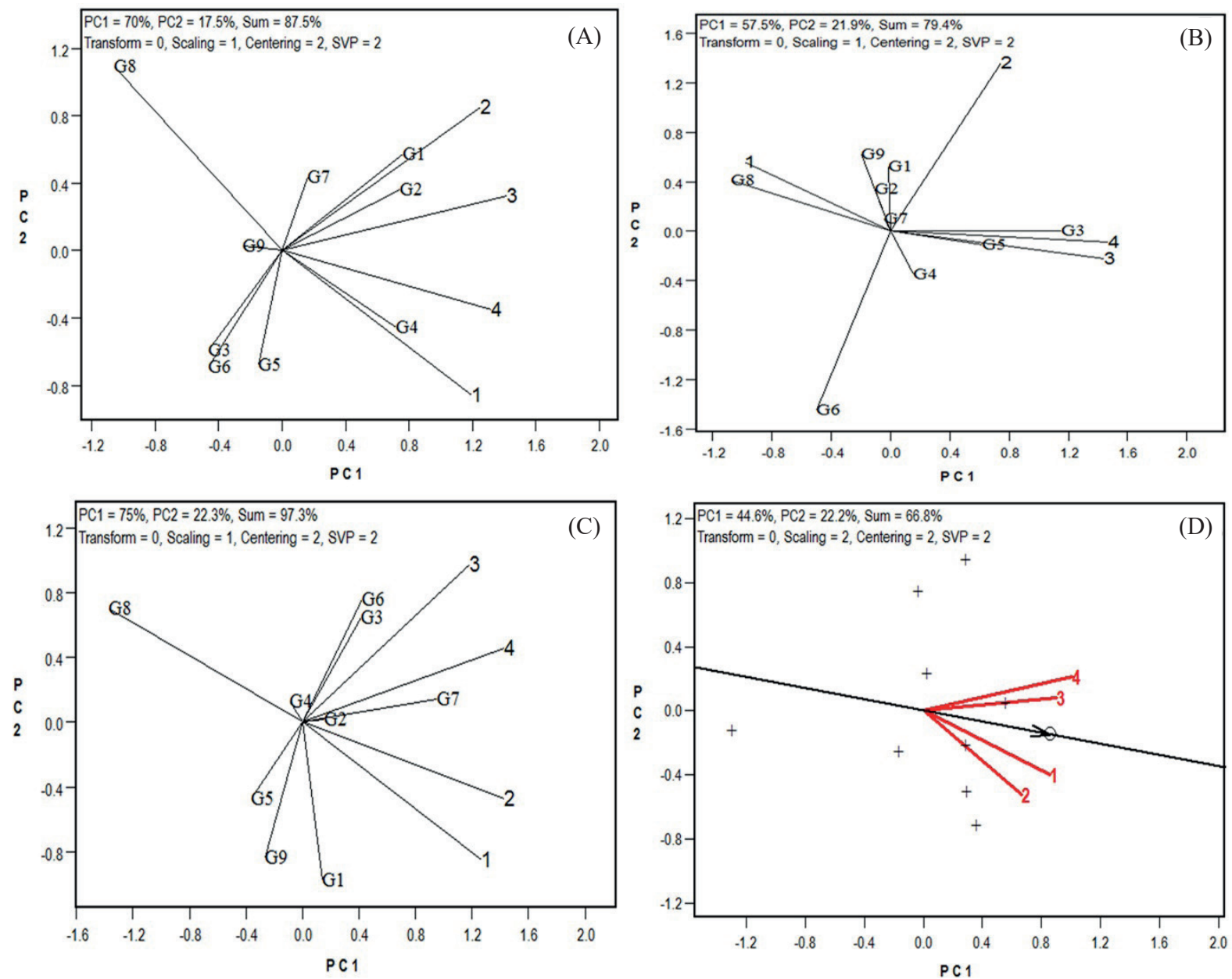

Figure 3. Association between genotypes (G1-G9) and growing environments (1, 2, 3 and 4), according to the GGE biplot model for 2013 (A), 2014 (B) and 2015 (C); representativeness and discrimination of tested environments for nine common bean genotypes in three growing years (D). 1: first crop under high technology; 2: first crop under low technology; 3: second crop under high technology; 4: second crop under low technology. G1: BRS Campeiro; G2: BRS Esplendor; G3: IPR Tuiuiú; G4: BRS Ametista; G5: BRS Estilo; G6: IPR 81; G7: IPR Campos Gerais; G8: IPR Curió; G9: IPR Tangará. 
respectively), BRS Esplendor (G2), Campos Gerais (G7) and BRS Campeiro (G1) obtained the best performance. For the second growing season under high technology (environment 3), IPR Tuiuiú (G3) obtained better performances, followed by IPR 81 (G6) under low technology (environment 4). Campos Gerais (G7) and BRS Esplendor (G2) were highlighted among the evaluated genotypes. IPR Campos Gerais (G7) and BRS Esplendor (G2) showed association among the environments, with a high stability and adaptability.

For breeding, it is important to know the ideal (discriminant and representative) environment to select the most suitable genotypes. In this way, the environments evaluated for common bean (Figure 3D) were analyzed considering three years of growth data (GGL + GGE). The results showed smaller angles between the vectors of environments 1 and 3 , in relation to the average environment axis. Thus, these are more representative environments for the target environment, where the genotype evaluation is more efficient for the selection and recommendation to all environments. Although less representative, the vectors of the environments 2 and 4 had angles of less than $90^{\circ}$ with the average environment axis, what indicates that they are also representative environments for the target region. The environments have a similar discriminative power, where $4 \approx 1>3 \approx 2$. Thus, for the genotypes evaluation and recommendation, the environment 1 can be considered as closer to the ideal, since it combines the representativeness of the target region and discrimination power of genotypes, with consistent results between growing years.

Both the environments 1 and 3 , corresponding to a high technology input in the first and second growing seasons (Figure 3D), were more representative than their low technology counterparts (environments 2 and 4). One reason that a high technological input allows for a greater representativeness may be that it allows a greater fungicide management and, therefore, greater control efficiency, in relation to the low technological input. According to Azevedo et al. (2015), even genotypes with high adaptabilities may present low stabilities due to susceptibility to pathogens, and this may be accentuated when grown under pathogenic conditions. The control of diseases through the use of fungicides helps to reduce the effects of diseases, generating a greater expressiveness of the genotypic part and less variation in the environmental effects, favoring the selection. Under high technology, an increase of $14.4 \%$ was observed, in relation to the low technological input. Thus, those environments are more representative for the selection of genotypes. Therefore, the genotype selection and recommendations in high technology environments allow to reproduce this performance in other environments.

\section{CONCLUSIONS}

1. A high technological input maximizes the grain yield potential of the common bean crop $(14.4 \%$, on average);

2. The IPR Campos Gerais genotype presents a better production stability under high and low technological inputs. This genotype is highlighted because of its high adaptability and response to the improvement of the environment;

3. In the first growing environment, IPR Campos Gerais and BRS Campeiro showed a performance closer to the ideal, while, in the second growing environment, IPR Tuiuiú showed the best performance.

\section{REFERENCES}

ALVARES, C. A. et al. Köppen's climate classification map for Brazil. Meteorologische Zeitschrift, v. 22, n. 6, p. 711-728, 2013.

ALVES, M. C.; POZZA, E. A. Indicator kriging modeling epidemiology of common bean anthracnose. Applied Geomatics, v. 2, n. 2, p. 65-72, 2010.

ARGAW, A.; MULETA, D. Inorganic nitrogen application improves the yield and yield traits of common bean (Phaseolus vulgaris L.) irrespective of the indigenous rhizobial population. South African Journal of Plant and Soil, v. 34, n. 2, p. 97-104, 2017.

AZEVEDO, C. V. G. et al. Adaptabilidade, estabilidade e resistência a patógenos em genótipos de feijoeiro. Pesquisa Agropecuária Brasileira, v. 50, n. 10, p. 912-922, 2015.

BARILI, L. D. et al. Genotype-environment interaction in common bean cultivars with Carioca grain, recommended for cultivation in Brazil in the last 40 years. Crop Breeding and Applied Biotechnology, v. 15, n. 4, p. 244-250, 2015.

BARROSO, A. A. M.; YAMAUTI, M. S.; ALVES, P. L. C. A. Interferência entre espécies de planta daninha e duas cultivares de feijoeiro em duas épocas de semeadura. Bragantia, v. 69, n. 3, p. 609-616, 2010. 
BEEBE, S. et al. Genetic improvement of common beans and the challenges of climate change. In: YADAV, S. S. et al. Crop adaptation to climate change. Oxford: WileyBlackwell, 2011. p. 356-369.

BEEBE, S. et al. Phenotyping common beans for adaptation to drought. Frontiers in Physiology, v. 4, n. 1, p. $35,2013$.

BORNHOFEN, E. et al. Statistical methods to study adaptability and stability of wheat genotypes. Bragantia, v. 76, n. 1, p. 1-10, 2017.

BRUNO, A. et al. Variety $\times$ environment $\times$ management interaction of diseases and yield in selected common bean varieties. Agronomy Journal, v. 109, n. 6, p. 2450-2462, 2017.

CARVAlHO, D. D. C. et al. Controle de Fusarium oxysporum f. sp. phaseoli in vitro e em sementes, e promoção do crescimento inicial do feijoeiro comum por Trichoderma harzianum. Tropical Plant Pathology, v. 36, n. 1, p. 28-34, 2011.

$\mathrm{CHI}$, Y. et al. Variations in grain cadmium and arsenic concentrations and screening for stable low-accumulating rice cultivars from multi-environment trials. Science of the Total Environment, v. 643, n. 1, p. 1314-1324, 2018.

COMPANHIA NACIONAL DE ABASTECIMENTO (Conab). Acompanhamento da safra brasileira de grãos. 2019. Available at: <https://www.conab.gov.br/info-agro/safras/ graos/boletim-da-safra-de-graos>. Access on: 30 May 2019.

COSTA, J. G. C. et al. BRS Esplendor: cultivar de feijoeiro comum de grão tipo comercial preto, com arquitetura de planta ereta, alto potencial produtivo e tolerância a doenças. Santo Antônio de Goiás: Embrapa Arroz e Feijão, 2009.

CRUZ, C. D. Genes software: extended and integrated with the R, Matlab and Selegen. Acta Scientiarum, v. 38, n. 4, p. 547-552, 2016.

CUNHA, J. P. A. R.; TEIXEIRA, M. M.; VIEIRA, R. F. Avaliação de pontas de pulverização hidráulicas na aplicação de fungicida em feijoeiro. Ciência Rural, v. 35, n. 5, p. 1069-1074, 2005.

DEVI, M. J. et al. Comparison of common bean (Phaseolus vulgaris L.) genotypes for nitrogen fixation tolerance to soil drying. Plant and Soil, v. 364, n. 1-2, p. 29-37, 2013.

DIPP, C. C. et al. Drought stress tolerance in common bean: what about highly cultivated Brazilian genotypes? Euphytica, v. 213, n. 5, p. 102, 2017.

EUZEBIO, M. P. et al. Adaptability and stability assessment of bean cultivars of the carioca commercial group by a Bayesian approach. Acta Scientiarum Agronomy, v. 40, e35015, 2018.
FAGERIA, N. K. et al. Dry matter, grain yield, and yield components of dry bean as influenced by nitrogen fertilization and rhizobia. Communications in Soil Science and Plant Analysis, v. 45, n. 1, p. 111-125, 2014.

FARID, M.; EARL, H. J.; NAVABI, A. Yield stability of dry bean genotypes across nitrogen-fixation-dependent and fertilizer-dependent management systems. Crop Science, v. 56, n. 1, p. 173-182, 2016.

GONÇALVES, J. G. R. et al. Estudo da estabilidade fenotípica de feijoeiro com grãos especiais. Ciência $e$ Agrotecnologia, v. 34, n. 4, p. 922-931, 2010.

HEINEMANN, A. B. et al. Drought impact on rainfed common bean production areas in Brazil. Agricultural and Forest Meteorology, v. 225, n. 1, p. 57-74, 2016.

HOYOS-VILLEGAS, V.; WRIGHT, E. M.; KELLY, J. D. GGE biplot analysis of yield associations with root traits in a Mesoamerican bean diversity panel. Crop Science, v. 56, n. 3, p. 1081-1094, 2016.

JUROSZEK, P.; VON TIEDEMANN, A. Potential strategies and future requirements for plant disease management under a changing climate. Plant Pathology, v. 60, n. 1, p. 100-112, 2011.

KAYA, Y.; AKÇURA, M.; TANER, S. GGE-biplot analysis of multi-environment yield trials in bread wheat. Turkish Journal of Agriculture and Forestry, v. 30, n. 5, p. 325-337, 2006.

LIMA, L. K. et al. Repeatability of adaptability and stability parameters of common bean in unpredictable environments. Pesquisa Agropecuária Brasileira, v. 48, n. 9, p. 1254-1259, 2013.

LUO, Q. Temperature thresholds and crop production: a review. Climatic Change, v. 109, n. 3-4, p. 583-598, 2011.

MACHADO, A. B. et al. Rendimento de grãos de feijão e nível de dano econômico sob dois períodos de competição com Euphorbia heterophylla. Planta Daninha, v. 33, n. 1, p. 41-48, 2015.

MATEI, G. et al. Desempenho agronômico de cultivares modernas de soja em ensaios multiambientes. Pesquisa Agropecuária Brasileira, v. 52, n. 7, p. 500-511, 2017.

MATOS, J. W.; RAMALhO, M. A. P.; ABREU, A. F. B. Trinta e dois anos do programa de melhoramento genético de feijoeiro comum em Minas Gerais. Ciência e Agrotecnologia, v. 31, n. 6, p. 1749-1754, 2007.

MCCREARY, C. M. et al. Fungicide efficacy of dry bean white mold [Sclerotinia sclerotiorum (Lib.) de Bary, causal organism] and economic analysis at moderate to high disease pressure. Crop Protection, v. 82, n. 1, p. 75$81,2016$. 
MELO, L. C. et al. Common bean cultivar BRS Ametista with large Carioca grains and disease resistance. Crop Breeding and Applied Biotechnology, v. 12, n. 4, p. 293296, 2012.

MELO, L. C. et al. Interação com ambientes e estabilidade de genótipos de feijoeiro-comum na região centro-sul do Brasil. Pesquisa Agropecuária Brasileira, v. 42, n. 5, p. 715-723, 2007.

MONTANARI, R. et al. Aspectos da produtividade do feijão correlacionados com atributos físicos do solo sob elevado nível tecnológico de manejo. Revista Brasileira de Ciência do Solo, v. 34, n. 6, p. 1811-1822, 2010.

MOURA, A. D.; BRITO, L. M. Aspectos econômicos. In: CARNEIRO, J. E.; PAULA JÚNIOR, T. J.; BORÉM, A. Feijão: do plantio à colheita. Viçosa: Ed. UFV, 2015. p. 16-37.

PEREIRA, H. S. et al. Genotype by environment interaction for disease resistance and other important agronomic traits supporting the indication of common bean cultivars. Euphytica, v. 214, n. 12, p. 1-11, 2018.

PEREIRA, H. S. et al. Stability and adaptability of Carioca common bean genotypes in states of the central south region of Brazil. Crop Breeding and Applied Biotechnology, v. 9, n. 2, p. 181-188, 2009.

RAMALHO, M. A. P.; ABREU, A.; SANTOS, P. S. J. dos. Interações genótipos $x$ épocas de semeadura, anos e locais na avaliação de cultivares de feijão nas regiões sul e Alto Paranaíba em Minas Gerais. Santo Antônio de Goiás, Embrapa Arroz e Feijão, 1998.

ROSALES-SERNA, R. et al. Biomass distribution, maturity acceleration and yield in drought-stressed common bean cultivars. Field Crops Research, v. 85, n. 2-3, p. 203-211, 2004.

SAIREKHA, K. et al. GGE biplot analysis for thermo sensitive genic male sterile lines of rice (Oryza sativa L.) in multi-environment trials. International Journal of Current Microbiology and Applied Sciences, v. 7, n. 1, p. 186-195, 2018.

SANTOS, H. G. et al. Sistema brasileiro de classificação de solos. Rio de janeiro: Embrapa Solos, 2013.

SANTOS, L. A. et al. Crescimento, índices fisiológicos e produtividade de cultivares de feijoeiro sob diferentes níveis de adubação. Revista Ceres, v. 62, n. 1, p. 107-116, 2015.

SANTOS, P. R. et al. GGE biplot and REML/BLUP basedanalysis of yield stability and adaptability for common beans in multi-environment trials. Brazilian Journal of Agricultural Sciences, v. 14, n. 2, p. 1-8, 2019.
SILVA, G. A. P. et al. Análise da adaptabilidade e estabilidade de produção em ensaios regionais de feijoeiro para o estado de São Paulo. Revista Ceres, v. 60, n. 1, p. 59-65, 2013.

SOCIEDADE BRASILEIRA DE CIÊNCIA DO SOLO (SBCS). Comissão de Química e Fertilidade do Solo. Manual de adubação e de calagem para os estados do Rio Grande do Sul e Santa Catarina. Porto Alegre: SBCS, 2004.

SOUZA, M. B. E. et al. Genotype by environment interaction in cowpea lines using GGE biplot method. Revista Caatinga, v. 31, n. 1, p. 64-71, 2018.

SOZEN, O. et al. Genotype x environment interaction of some dry bean (Phaseolus vulgaris L.) genotypes. Legume Research, v. 41, n. 2, p. 189-195, 2018.

TOHME, M. et al. The combined use of agroecological and characterisation data to establish the CIAT Phaseolus vulgaris core collection. In: HODGKIN, T. (Eds.). Core collections of plant genetic resources. Rome: International Plant Genetic Resources Institute, 1995. p. 95-107.

TORGA, P. P. et al. Interaction of common beans cultivars of the black group with years, locations and sowing seasons. Euphytica, v. 189, n. 2, p. 239-248, 2013.

TRINDADE, R. S.; ARAÚJO, A. P. Variability of root traits in common bean genotypes at different levels of phosphorus supply and ontogenetic stages. Revista Brasileira de Ciência do Solo, v. 38, n. 4, p. 1170-1180, 2014.

UNITED STATES DEPARTMENT OF AGRICULTURE (USDA). Keys to soil taxonomy. 12. ed. Washington, DC: USDA-Natural Resources Conservation Service, 2014.

YAN, W. Analysis and handling of $\mathrm{G} \times \mathrm{E}$ in a practical breeding program. Crop Science, v. 56, n. 5, p. 2106-2118, 2016.

YAN, W. Crop variety trials: data management and analysis. Hoboken: John Wiley \& Sons, 2014.

YAN, W. GGE biplot: a Windows application for graphical analysis of multienvironment trial data and other types of two-way data. Agronomy Journal, v. 93, n. 5, p. 1111$1118,2001$.

YAN, W. Mega-environment analysis and test location evaluation based on unbalanced multiyear data. Crop Science, v. 55, n. 1, p. 113-122, 2015.

YAN, W.; HOLLAND, J. B. A heritability-adjusted GGE biplot for test environment evaluation. Euphytica, v. 171, n. 3, p. 355-369, 2010. 